\title{
Elemental composition of depth samples of Ceratium hirundinella (Pyrrophyta) within a stratified lake: an X-ray microanalytical study
}

\author{
David C. Sigee*, Eugenia Levado, Andrew J. Dodwell \\ School of Biological Sciences, The University of Manchester, 3.614 Stopford Building, Oxford Road, \\ Manchester M13 9PT, United Kingdom
}

\begin{abstract}
The elemental composition of Ceratium hirundinella cells was investigated in mixed phytoplankton samples collected from the water column of a stratified lake. X-ray microanalysis (XRMA) routinely detected $\mathrm{Mg}, \mathrm{Si}, \mathrm{P}, \mathrm{Cl}, \mathrm{K}$ and $\mathrm{Ca}$ with occasional peaks of $\mathrm{Na}, \mathrm{Al}$ and $\mathrm{Fe}$. Cell concentrations of most elements showed no significant variation within the epilimnion, but $\mathrm{Mg}, \mathrm{P}, \mathrm{Cl}$ and $\mathrm{K}$ were significantly lower (and Si higher) in cells from the metalimnion. Ratios of $\mathrm{Mg} / \mathrm{K}, \mathrm{P} / \mathrm{K}, \mathrm{Mg} / \mathrm{P}$ monovalent/divalent cations and diffusible anions/cations were constant throughout the sampled water column. Within depth populations of Ceratium, concentrations of each element varied considerably, approximating (except Si) to a normal distribution. Approximately $5 \%$ of all cells had abnormally low concentrations of $\mathrm{K}$ and were possibly undergoing senescence. Correlation and factor analysis demonstrated a major statistical association between Mg, P, S and K in Ceratium cells throughout the depth samples. The XRMA results suggest an underlying homogeneity in the population of Ceratium throughout the sampled water column, consistent with the known high mobility and rapid migration of these cells within the water body.
\end{abstract}

KEY WORDS: Phosphorus - X-ray microanalysis - Ceratium - Dinoflagellates - Water column - Anions · Cations

\section{INTRODUCTION}

Studies on the elemental composition of freshwater phytoplankton have normally involved the use of bulk analysis techniques, such as atomic absorption spectrophotometry (Behrendt 1990), providing mean data for the whole plankton sample. The recent development of electron-probe X-ray microanalysis (XRMA) as a routine analytical technique (Sigee et al. 1993) now permits a more detailed study of the elemental composition of freshwater biota, since it combines high spatial resolution (single cell analysis) with simultaneous detection of a range of elements (determination of elemental ratios and correlations). XRMA has been used for determining the elemental composition of a range of phytoplankton species (Clay et al. 1991, ElBestawy et al. 1996, Sigee \& Holland 1997, Sigee et al.

•E-mail: david.sigee@man.ac.uk
1998) as well as lake bacteria (Booth et al. 1987). Other single-cell techniques that have been used to determine the chemical composition of phytoplankton cells include proton-probe analysis (Brook et al. 1988) and chemiluminescence (Villareal \& Lipschultz 1995).

The present study was carried out on the dinoflagellate Ceratium hirundinella (O.F. Mull.) (hereafter Ceratium). This alga is frequently encountered as a major constituent of freshwater lakes, where it is found over a wide range of trophic conditions (Höll 1928). Studies were carried out at Rostherne Mere (Cheshire, UK), a deep eutrophic lake (Carvalho et al. 1995, Moss et al. 1997) that regularly stratifies during summer months. At this site, Ceratium typically co-dominates with Microcystis aeruginosa in late summer (Reynolds \& Bellinger 1992), occasionally reaching population levels in excess of $10^{3}$ cells $\mathrm{ml}^{-1}$

The elemental composition of Ceratium is of particular interest, since recent XRMA studies (Sigee et al. 
1998) have demonstrated marked temporal variations between micro-populations of this alga in relation to changes in water chemistry. In addition to major differences between populations, considerable variation also occurred in the elemental composition of individual Ceratium cells within each phytoplankton sample, possibly relating to the different depths sampled within the integrated sample.

The major purpose of the present study was to determine variation in the elemental composition of this alga with depth, analysing micro-populations of Ceratium within phytoplankton samples collected at different points within the water column. As far as we are aware, this is the first published investigation of singlespecies depth variation in elemental composition within the lake environment. Such variation in cell chemistry might arise due to variation in physical and chemical properties of micro-environment with depth, and would clearly relate to both lake stratification and the mobility of Ceratium within the water body. Depth variations in the elemental composition of phytoplankton species have significance in relation to biodiversity within the freshwater environment and also have implications for modelling studies on lake nutrient cycling (Krivtsov et al. 1998).

\section{MATERIALS AND METHODS}

Collection and processing of samples. Sampling was carried out at midday on August 5, 1997, at a central point (total depth $30 \mathrm{~m}$ ) in Rostherne Mere, Cheshire, UK, as part of a regular sampling programme at this site. $2 \mathrm{l}$ samples of lake water were collected at the surface $(0 \mathrm{~m})$ and at depths of 1,2,5 and $8 \mathrm{~m}$. Physical parameters were also noted at these depths, including temperature, $\mathrm{pH}$, conductivity and oxygen concentration. Secchi depth was also recorded.

The 2 l depth samples were subdivided for collection of phytoplankton samples, cell population counts, chlorophyll a (chl a) determination and water analysis Phytoplankton samples for XRMA were immediately collected by filtering $50 \mathrm{ml}$ of lake water through a $5.0 \mu \mathrm{m}$ polycarbonate (Nuclepore) filter membrane contained in a small filtration apparatus (Swinnex disc filter holder, Millepore Corp.). Excess lake water was removed by passing air through the filtration system. Filter membranes were inmediately removed and plunge-frozen in liquid nitrogen $\left(-196^{\circ} \mathrm{C}\right)$ while on the boat. Samples were transported back to the laboratory in liquid nitrogen for further processing For cell counts, Lugol's iodine was added to $200 \mathrm{ml}$ of lake water, and counts subsequently made in the laboratory using a Sedgwick rafter slide, according to standard procedures.
Water analysis and chl a determination. Filtered lake water samples were analysed for soluble inorganic nitrate and soluble inorganic phosphate concentrations using a Skalar mass flow autoanalyser (Skalar Analytical B.V.). Elemental concentrations were determined by inductively coupled plasma atomic emission spectroscopy (ICP-AES, Fison VG Elemental Horizon spectrometer) from lake water samples that had been filtered through a $0.45 \mu \mathrm{m}$ Nuclepore filter membrane, then acidified with Aristar quality nitric acid.

Chl a determinations were carried out according to the cold ethanol extraction procedure of Jespersen \& Christoffersen (1987). A known volume of sample was filtered onto a $47 \mathrm{~mm}$ Whatman GF/C filter, and stored at $-20^{\circ} \mathrm{C}$ prior to processing. Filters were then ground into small pieces, placed in $5 \mathrm{ml}$ of $96 \%$ ethanol in $25 \mathrm{ml}$ universals and maintained for $20 \mathrm{~h}$ at $5^{\circ} \mathrm{C}$. Universals were then centrifuged for $10 \mathrm{~min}$ at $3000 \mathrm{rpm}$ $(1800 \times g)$. UV absorption of the extract (supernatant) was measured at $665 \mathrm{~nm}$ ( $\mathrm{chl} \mathrm{a}$ ) and $750 \mathrm{~nm}$ (turbidity) using a Pye Unicam ultraviolet spectrophotometer. The chl a concentration was subsequently determined using the standard formula of Jespersen \& Christoffersen (1987).

X-ray microanalysis. Membrane phytoplankton samples were transferred from liquid nitrogen to the pre-cooled stage $\left(-60^{\circ} \mathrm{C}\right)$ of an Edwards tissue-drier and freeze-dried over a $12 \mathrm{~h}$ period at $10^{-2}$ torr. Samples were subsequently mounted on SEM stubs and carbon coated (NanoTech coating unit) according to standard procedures.

XRMA was carried out in a Cambridge 360 scanning electron microscope, with Kevex detector and LINK AN10000 analyser. X-ray emission spectra were collected from the central region of individual Ceratium cells (see Fig. 2), using a raster of approximately $30 \times$ $20 \mu \mathrm{m}$ in size. X-rays were collected over a livetime of $100 \mathrm{~s}$, at an accelerating voltage of $15 \mathrm{kV}$ and magnification of $1.4 \mathrm{~K}$. The detector-specimen distance was set at $25 \mathrm{~mm}$, with a take-off angle of $35^{\circ}$. Probe current was typically about $500 \mathrm{pA}$ and was adjusted to give an $X$-ray count of $10^{3} \mathrm{cps}$.

Quantification was carried out using the LINK ZAF/ $\mathrm{PB}$ programme for elements within a protein matrix, with cobalt as the reference element. Stored spectral information from inorganic standards is used in this programme for gain calibration and for determination of goodness of fit of elemental peaks in cell spectra. Analyses with a fit index greater than 2 were discarded. Elemental peaks within Ceratium spectra were considered significant when:

$$
\left(P^{\prime}-B\right)>2 \sqrt{ }\left(P^{\prime}+B\right)
$$

where $P^{\prime}=$ total peak integral, and $B=$ estimated continuum component of peak integral. 
Table 1. Concentrations of major anions, cations and algal biomass in the water column. Ion concentrations are expressed as mg $1^{-1}$, chlorophyll a (chl a) as $\mu \mathrm{I}^{-1}$ and Ceratium hirundinella counts as cells $\mathrm{ml}^{-1} \mathrm{~N}$, Si, P and S are soluble inorganic nitrogen, silicon, phosphorus and sulphur, respectively

\begin{tabular}{|c|c|c|c|c|c|c|c|c|c|}
\hline \multirow{2}{*}{ Depth $(\mathrm{m})$} & \multicolumn{4}{|c|}{ Anions } & \multicolumn{3}{|c|}{ Cations } & \multicolumn{2}{|c|}{ Biomass } \\
\hline & $N$ & $\mathrm{Si}$ & $\mathrm{P}$ & $s$ & $\mathrm{Mg}$ & K & $\mathrm{Ca}$ & Chl a & C. hirundinella \\
\hline 0 & 0.81 & 0.83 & 0.103 & 26.85 & 12.19 & 4.79 & 57.51 & 13.19 & 20 \\
\hline 1 & 0.81 & 0.84 & 0.083 & 27.72 & 12.11 & 4.78 & 58.36 & 13.91 & 50 \\
\hline 2 & 0.83 & 0.82 & 0.103 & 28.77 & 12.06 & 5.02 & 58.87 & 13.79 & 30 \\
\hline 5 & 0.86 & 0.88 & 0.098 & 31.57 & 12.46 & 4.96 & 61.05 & 15.47 & 40 \\
\hline 8 & 1.24 & 1.02 & 0.146 & 31.00 & 12.37 & 5.21 & 61.57 & 4.20 & 20 \\
\hline
\end{tabular}

Further details of the XRMA quantitation programme and procedures are given in Sigee \& Holland (1997). Elemental concentrations within cells were initially determined as percentage dry weight and subsequently converted to $\mathrm{mmol} \mathrm{\textrm {kg } ^ { - 1 }}$ dry wt. Absolute values of elemental mass and total cell mass were not determined. The accuracy of quantitation was verified using gelatin standards containing known elemental concentrations (described in Hall et al. 1992). With each depth sample a total of 40 individual Ceratium cells were randomly selected and analysed. Only elements present as significant peaks in at least $50 \%$ of the emission spectra were included in the quantitative analysis. Statistical tests were carried out using Excel (Microsoft Ltd) and SPSS (SPSS Ltd) software.

\section{RESULTS}

\section{Environmental parameters and population counts}

Lake stratification. Well-defined stratification of the water column at the sampling site is shown by temperature and oxygen saturation profiles (Fig. 1). The epilimnion (mean temperature $18.5^{\circ} \mathrm{C}$, mean oxygen saturation $92.7 \%$ ) extended to a depth of approximately $6 \mathrm{~m}$, with a transitional metalimnion down to $16 \mathrm{~m}$. Below this the hypolimnion stabilised to a temperature of $7.6^{\circ} \mathrm{C}$ and oxygen saturation fell to zero.

Ion concentrations. Concentrations of major anions and cations in lake water are shown in Table 1 . Soluble inorganic nitrogen and phosphorus ranged from 0.81 to $1.24 \mathrm{mg} \mathrm{l}^{-1}$ and 0.083 to $0.146 \mathrm{mg} \mathrm{l}^{-1}$, respectively, with highest concentrations at $8 \mathrm{~m}$ depth in both cases. Soluble $\mathrm{Si}$ also showed a maximum concentration at $8 \mathrm{~m}$. Concentrations of major cations showed little variation within the water column, though in all cases the concentration was highest at the epilimnion/hypolimnion boundary ( 5 and $8 \mathrm{~m}$ depths). Conductivity of the integrated sample was $480 \mu \mathrm{Si}$.

Algal biomass. Chl a concentrations ranged from 13.19 to $15.47 \mathrm{\mu g} \mathrm{l}^{-1}$ throughout the epilimnion, falling to $4.20 \mathrm{ug}^{-1}$ at the top of the hypolimnion. Secchi depth was $1.9 \mathrm{~m}$. Population counts of Ceratium (20 to 50 cells $\mathrm{ml}^{-1}$ ) indicated that this alga was present as a major constituent of the phytoplankton throughout the sampled water column.

\section{X-ray microanalysis emission spectra}

The appearance of a typical mixed phytoplankton sample, taken from a depth of $2 \mathrm{~m}$, is shown in Fig. 2a, and a single Ceratium cell (with position of probe area) in Fig. 2b. X-ray emission spectra typically demonstrated clear peaks of monovalent $(\mathrm{K})$ and divalent ( $\mathrm{Mg}, \mathrm{Ca}$ ) cations, plus peaks of Si, P, S and Cl (Fig. 3). The peak of $\mathrm{Na}$ was normally smail fbeing at the low
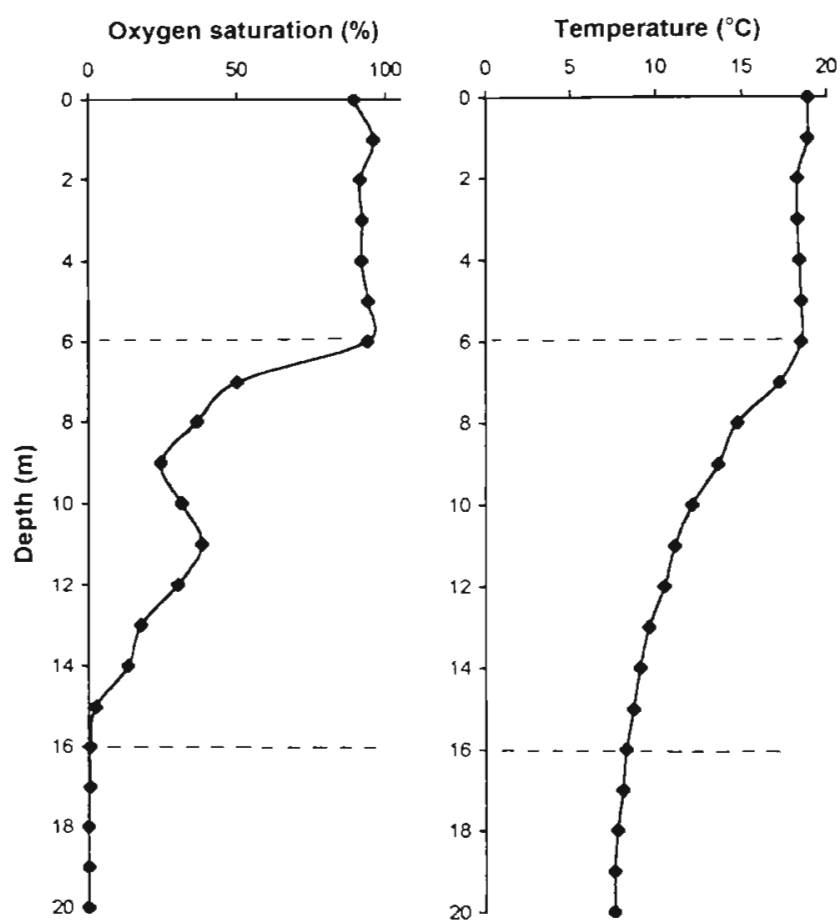

Fig. 1. Stratification of the water column. Approximate upper limits of the metalimnion $(6 \mathrm{~m})$ and hypolimnion $(16 \mathrm{~m})$ are indicated by broken lines 


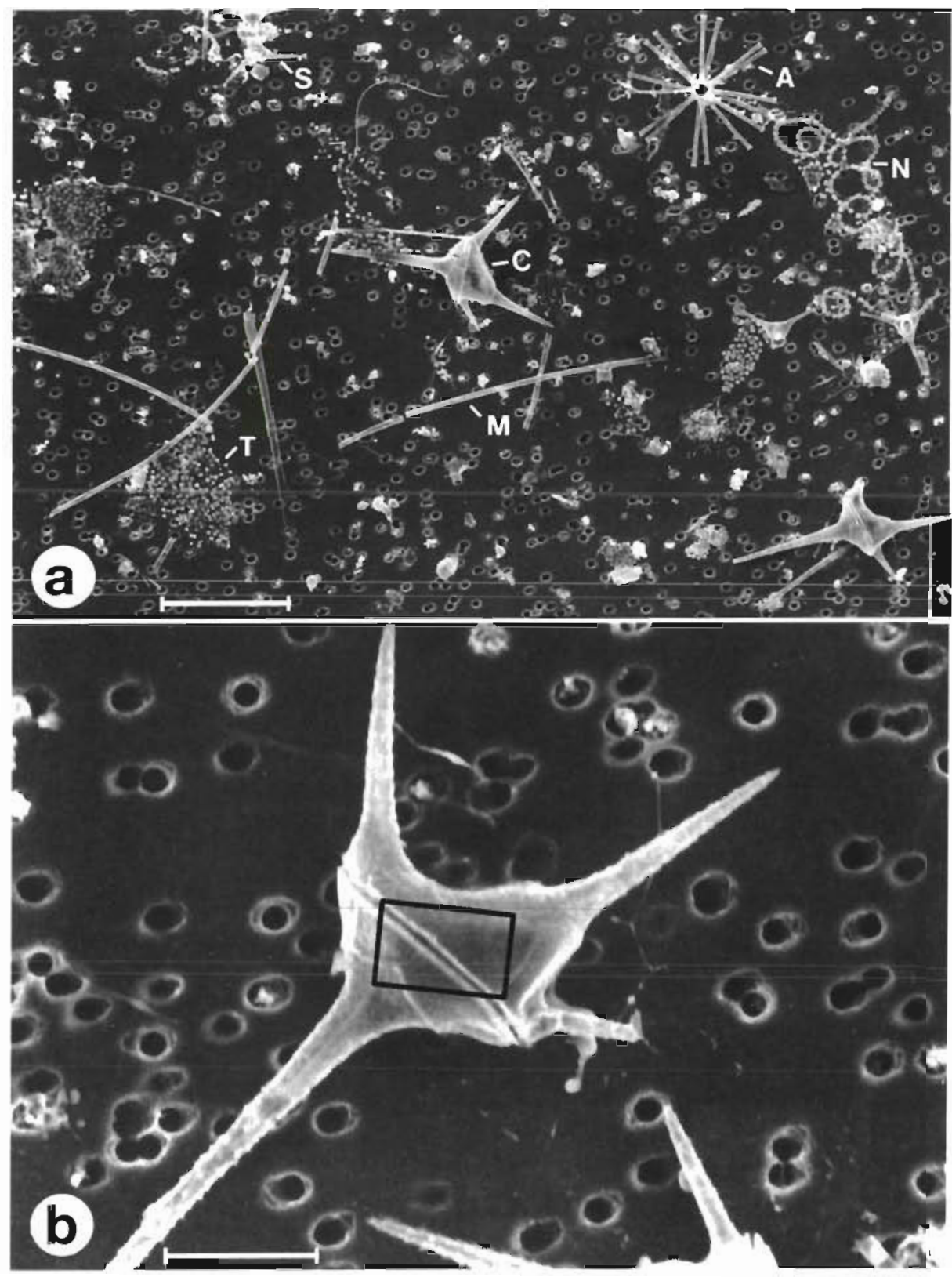

Fig. 2. Scanning electron micrographs of freeze-dried $2 \mathrm{~m}$ phytoplanktor sample. (a) Low power view of carbon-coated mixed phytoplankton sample, showing specimens of Asterionella (A), Ceratium (C), Melosira (M), Anabaena (N), Microcystis (T) and Staurastrum (S). Scale bar $=100 \mu \mathrm{m}$. (b) Single cell of $C$. hirundinella from the above sample, showing details of surface structure and equatorial groove. The typical size and position of the microprobe raster is indicated as a rect. angle. Scale bar $=30 \mu \mathrm{m}$

atomic number end of the spectrum), and peaks of $\mathrm{Al}$ and Fe were occasionally seen. XRMA spectra taken from areas of membrane close to analysed cells typically had no clear elemental (characteristic) peaks.

\section{Elemental concentrations}

Comparison of depth samples. Mean cell concentrations of some of the major elements showed clear differences within the water column (Table 2). This was particularly the case for Si, which increased markedly in the 5 and $8 \mathrm{~m}$ samples. Other elements typically showed a fall in intracellular concentration in the deeper samples, with significantly lower concentrations occurring for $\mathrm{Mg}$ and $\mathrm{Cl}(8 \mathrm{~m}), \mathrm{K}(2$ to $8 \mathrm{~m})$ and $\mathrm{P}$ ( 2 and $8 \mathrm{~m}$ ). S and Ca showed little variation within the water column.

No significant differences were detected for $\mathrm{Na}, \mathrm{Al}$ and Fe. This partly arose because the overall detectability of these elements within all the depth samples was less than $50 \%$, making valid statistical analysis difficult.

Variation within micro-populations. Considerable variation in elemental concentrations occurred between individual cell analyses within each depth sample. This is shown, for example, in the $2 \mathrm{~m}$ sample 
Fig. 3. X-ray emission spectra from freeze-dried Ceratium hirundinella cells present in the 1 and $5 \mathrm{~m}$ depth samples. The bottom spectrum is taken from a region of Nuclepore support membrane close to the cell analysed in the $1 \mathrm{~m}$ sample. No characteristic peaks are present

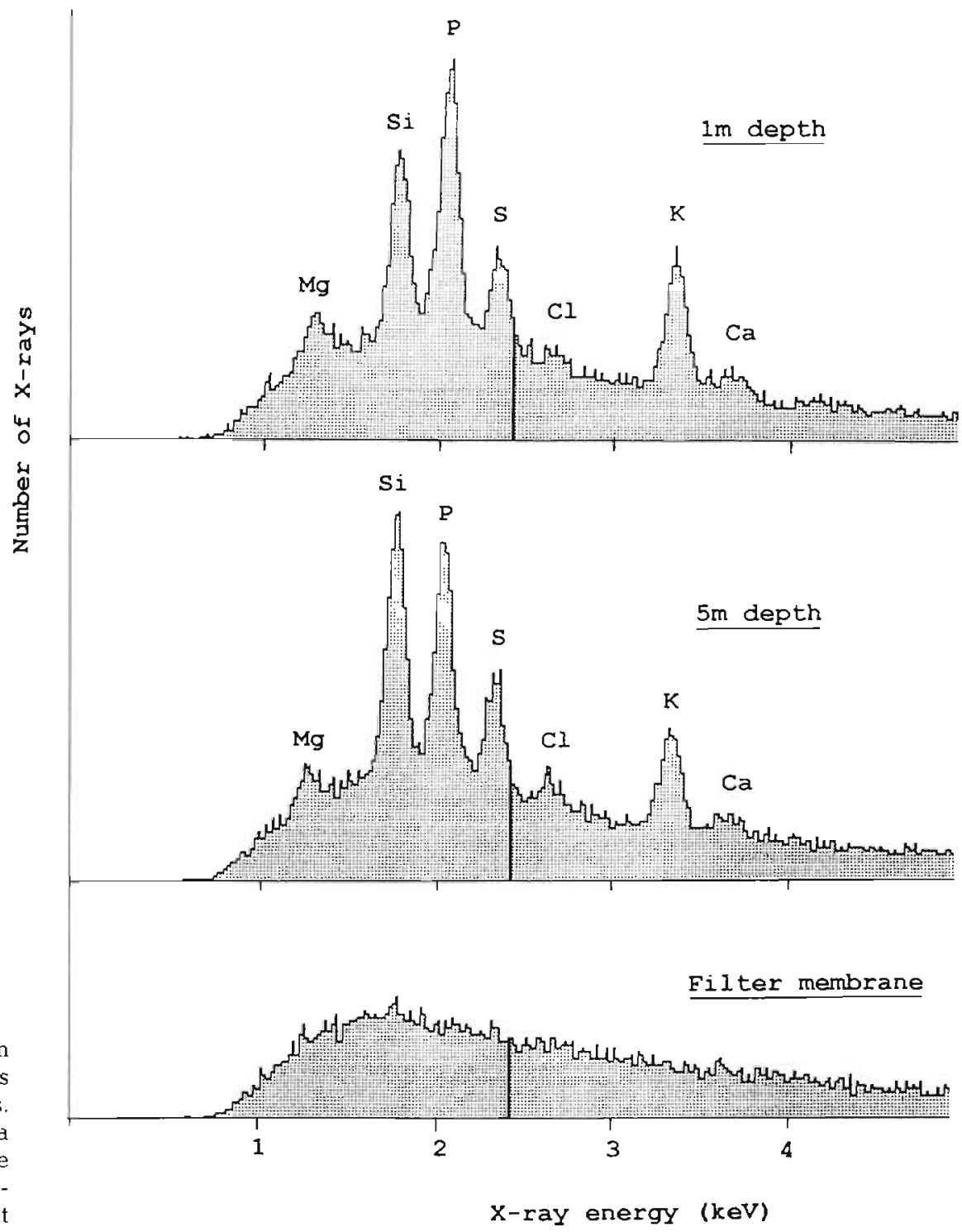

Table 2. Mean elemental concentrations in Ceratium hirundinella at difterent depths in the water column. For each depth sample, mean elemental concentrations are given as $\mathrm{mmol} \mathrm{kg}^{-1}$ dry wt ( $\pm \mathrm{SE}$ ). $\mathrm{n}=40$. Overall mean and \% detectability are based on all analysed cells in the water column $(n=200)$

\begin{tabular}{|c|c|c|c|c|c|c|c|c|c|c|}
\hline Depth $(\mathrm{m})$ & $\mathrm{Na}$ & $\mathrm{Mg}$ & $\mathrm{Al}$ & $\mathrm{Si}$ & $P$ & S & $\mathrm{Cl}$ & $\mathrm{K}$ & $\mathrm{Ca}$ & $\mathrm{Fe}$ \\
\hline 0 & $\begin{array}{r}33^{b} \\
( \pm 5)\end{array}$ & $\begin{array}{l}131^{a} \\
( \pm 6)\end{array}$ & $\begin{array}{r}8^{\mathrm{b}} \\
( \pm 4)\end{array}$ & $\begin{array}{r}684^{\mathrm{a}} \\
( \pm 92)\end{array}$ & $\begin{array}{c}352 \\
( \pm 13)\end{array}$ & $\begin{array}{l}132^{\mathrm{a}} \\
( \pm 4)\end{array}$ & $\begin{array}{r}46^{\mathrm{a}} \\
( \pm 3)\end{array}$ & $\begin{array}{l}181 \\
( \pm 5)\end{array}$ & $\begin{array}{c}24 \\
( \pm 2)\end{array}$ & $\begin{array}{r}7^{\mathrm{b}} \\
( \pm 2)\end{array}$ \\
\hline 1 & $\begin{array}{r}27^{b} \\
( \pm 3)\end{array}$ & $\begin{array}{l}132^{\mathrm{a}} \\
( \pm 7)\end{array}$ & $\begin{array}{r}9^{\mathrm{b}} \\
( \pm 2)\end{array}$ & $\begin{array}{r}409^{\circ} \\
( \pm 40)\end{array}$ & $\begin{array}{c}345 \\
( \pm 15)\end{array}$ & $\begin{array}{l}151 \\
( \pm 6)\end{array}$ & $\begin{array}{r}45^{\mathrm{a}} \\
( \pm 2)\end{array}$ & $\begin{array}{l}188 \\
( \pm 7)\end{array}$ & $\begin{array}{c}30 \\
( \pm 2)\end{array}$ & $\begin{array}{r}42 \\
( \pm 20)\end{array}$ \\
\hline 2 & $\begin{array}{r}29^{\mathrm{b}} \\
( \pm 3)\end{array}$ & $\begin{array}{l}118^{a} \\
( \pm 6)\end{array}$ & $\begin{array}{r}7^{b} \\
( \pm 2)\end{array}$ & $\begin{array}{r}415^{a} \\
( \pm 48)\end{array}$ & $\begin{array}{r}294^{\mathrm{a}} \\
( \pm 14)\end{array}$ & $\begin{array}{l}135^{d} \\
( \pm 6)\end{array}$ & $\begin{array}{r}50^{\mathrm{a}} \\
( \pm 3)\end{array}$ & $\begin{array}{l}157^{a} \\
( \pm 8)\end{array}$ & $\begin{array}{c}30 \\
( \pm 2)\end{array}$ & $\begin{array}{c}46 \\
( \pm 5)\end{array}$ \\
\hline 5 & $\begin{array}{r}30^{b} \\
( \pm 4)\end{array}$ & $\begin{array}{l}121^{a} \\
( \pm 6)\end{array}$ & $\begin{array}{r}5^{\mathrm{b}} \\
( \pm 1)\end{array}$ & $\begin{array}{c}1280 \\
( \pm 161)\end{array}$ & $\begin{array}{c}327 \\
( \pm 15)\end{array}$ & $\begin{array}{l}137^{d} \\
( \pm 6)\end{array}$ & $\begin{array}{r}43^{\mathrm{a}} \\
( \pm 2)\end{array}$ & $\begin{array}{l}165^{a} \\
( \pm 6)\end{array}$ & $\begin{array}{c}30 \\
( \pm 2)\end{array}$ & $\begin{array}{c}19 \\
( \pm 2)\end{array}$ \\
\hline 8 & $\begin{array}{r}31^{\mathrm{b}} \\
( \pm 4)\end{array}$ & $\begin{array}{l}104 \\
( \pm 5)\end{array}$ & $\begin{array}{r}6^{\mathrm{b}} \\
( \pm 2)\end{array}$ & $\begin{array}{c}791 \\
( \pm 102)\end{array}$ & $\begin{array}{r}270^{a} \\
( \pm 12)\end{array}$ & $\begin{array}{l}127^{a} \\
( \pm 7)\end{array}$ & $\begin{array}{c}39 \\
( \pm 2)\end{array}$ & $\begin{array}{l}144^{\mathrm{a}} \\
( \pm 8)\end{array}$ & $\begin{array}{c}29 \\
( \pm 2)\end{array}$ & $\begin{array}{c}16 \\
( \pm 3)\end{array}$ \\
\hline Overall mean & 30 & 121 & 7 & 716 & 318 & 136 & 45 & 167 & 29 & 26 \\
\hline $\begin{array}{l}\text { Overall \% } \\
\text { detectability }\end{array}$ & 31 & 98 & 3 & 100 & 99 & 99 & 91 & 98 & 71 & 46 \\
\hline
\end{tabular}




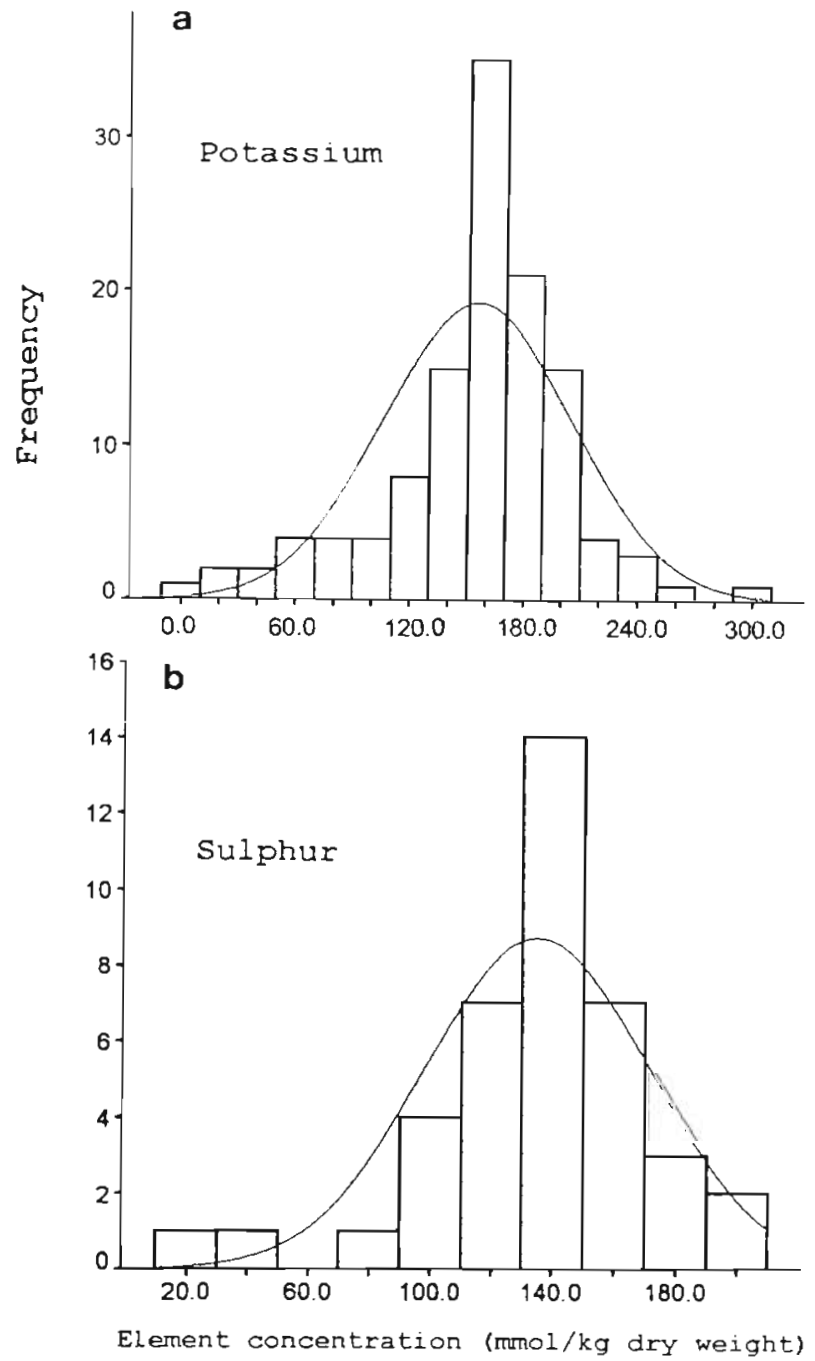

Fig. 4. Range of individual cell concentrations of $\mathrm{K}$ and $\mathrm{S}$ in micro-populations of Ceratium hirundinella. (a) Frequency distribution of potassium concentrations in 2,5 and $8 \mathrm{~m}$ samples (homogeneous subset, see Table 1). The graph shows a marked skew towards low potassium concentrations, and the observed data show a poor fit to the theoretical normal distribution (superimposed curve). Goodness of fit $(p)=0.02$, total population $(n)=120$. (b) Frequency distribution of sulphur in individual $C$. hirundinella cells within the $2 \mathrm{~m}$ sample. The observed data show a reasonable fit to the theoretical normal distribution $(p=0.73, n=40)$

(Fig. 4), where the concentration of sulphur varied from 20 to $200 \mathrm{mmol} \mathrm{kg}{ }^{-1}$ dry wt (mean value 135). Other elements in this depth sample showed a similar range of concentrations, including $\mathrm{Mg}$ (mean 118, range 0 to 200), Si (mean 415, range 103 to 1500), $\mathrm{P}$ (mean 294, range 16 to 458), $\mathrm{Cl}$ (mean 50, range 11 to 93), $K$ (mean 157, range 0 to 248) and Ca (mean 30 , range 5 to 55). Similar variations in elemental concentration occurred in the other depth samples.
Within each depth sample ( 40 cells) the distribution of major elemental concentrations was typically unimodal. With the exception of $\mathrm{Si}$, the range of elemental concentrations typically approximated to a normal distribution, with probability values for closeness of fit frequently in the range of 0.5 to 1.0. Deviation from normality occurred in some cases, however, resulting in part from a tendency of distributions to skew towards low concentration values. This was particularly clear for the major cation ( $K_{i}$ Fig. 4), where a proportion of values from 0 to $70 \mathrm{mmol} \mathrm{kg}^{-1}$ did not appear to be part of the normal distribution. Subtraction of cells with

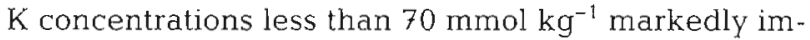
proved the closeness of fit ( $p$ value from 0.02 to 0.48 ), with much less improvement if cells below 50,60 and $80 \mathrm{mmol} \mathrm{kg}{ }^{-1}$ were subtracted.

Low $\mathrm{K}$ cells ( $\mathrm{K}$ less than $70 \mathrm{mmol} \mathrm{kg}^{-1}$ ) comprised $5.5 \%$ of cells in the complete set of depth samples (total of 200 ceils), and were present di depilus of $1 \mathrm{~m}$ ( 2 cells), $2 \mathrm{~m}$ ( 4 cells) $5 \mathrm{~m}$ ( 1 cell) and $8 \mathrm{~m}$ ( 4 cells). In addition to a low mean concentration of $\mathrm{K}$ (41 mmol $\mathrm{kg}^{-1}$ compared to an overall average of 167 ), these cells also had lower mean levels of $\mathrm{Mg}$ (55 compared to 121), Si (530 compared to 716), P (100 compared to 318) and $\mathrm{S}$ (67 compared to 136). Concentrations of $\mathrm{Na}(34$ compared to 30 ), $\mathrm{Cl}$ (50 compared to 45$)$ and $\mathrm{Ca}(38$ compared to 29) were little different.

\section{Elemental ratios}

Mean ratios of all detected elements were calculated for each depth sample and compared between depths to determine their consistency in micro-populations of Ceratium throughout the water column. Ten ratios were relatively constant throughout the depth samples ( $\mathrm{SE}<5 \%$ of overall mean), including $\mathrm{Mg} / \mathrm{K}$ (ratio 0.72 $\mathrm{SE} 1.15 \%$ of mean), $\mathrm{P} / \mathrm{K}(1.90,1.40 \%), \mathrm{Mg} / \mathrm{P}(0.38$ $1.52 \%)$ and $\mathrm{Mg} / \mathrm{S}(0.89,3.11 \%)$. Other elemental ratios were much more variable, including most ratios involving $\mathrm{Si}$ (e.g. Mg/Si, SE $21.21 \%$ of mean), Ca (e.g $\mathrm{P} / \mathrm{Ca}, 8.17 \%$ ) and $\mathrm{Fe}(\mathrm{e.g} . \mathrm{Fe} / \mathrm{P}, 29.4 \%)$.

\section{Ratios of inorganic anions and cations}

Constancy of ionic ratios were determined in relation to monovalent cations, monovalent/divalent cations and diffusible anions/cations.

Monovalent cations. The $\mathrm{K} / \mathrm{Na}$ ratio showed wide variation between samples, ranging from 4.7 to 7.1 . Within samples, $\mathrm{K}$ and $\mathrm{Na}$ did not show any significant positive correlations.

Monovalent/divalent cations. The ratio of detectable monovalent $(\mathrm{Na}+\mathrm{K})$ to divalent $(\mathrm{Mg}+\mathrm{Ca})$ cations 
was remarkably consistent throughout the samples, with an overall standard error of only $1.6 \%$ of the mean. Monovalent cations showed a high degree of correlation (95 to $99 \%$ level) with divalent cations in all depth samples.

Diffusible anions/cations. The ratio of detectable diffusible anions (Cl) to diffusible cations $(\mathrm{Na}+\mathrm{K})$ was relatively constant between samples, ranging from 0.21 to 0.27 (SE within $5 \%$ of meanj. Diffusible anions did not show any significant positive correlation with cations in any samples.

\section{Elemental correlations}

Statistical associations between individual elements within cells were investigated by correlation (Pearson correlation coefficients) and factor (principal component) analysis.

Correlation analysis. At each depth, clear correlation occurred between particular elements within the 40 cell sample. In the $2 \mathrm{~m}$ sample, for example, the correlation matrix (Table 3 ) reveals a total of 11 significant correlations (8 positive, 3 negative) out of a possible total of 35 . Regression analysis confirmed the high degree of correlation between particular elements (Fig. 5)

Comparison of elemental correlations within different depth samples showed that, although some variation occurred between samples, particular elemental pairs were consistently correlated. Two pairs of elements (Mg-P and P-K) were significantly (99\% level) and positively correlated in all samples, while others (Na-Mg, Mg-K, P-S, S-K) showed significant positive correlation in at least 3 samples. K-Fe were negatively correlated in 3 depth samples. Two major elements, Si and $\mathrm{Cl}$, did not show consistent ( 3 or more samples) correlations with any other elements

Factor analysis. For each depth sample, factor analysis was carried out on all elements present at detectable levels in $50 \%$ of cells (see Table 2). In almost all cases, the Kaiser-Meyer-Olkin (KMO) index was greater than 0.5 and the Bartlett test of sphericity was significant, indicating that the sample was suitable for factor analysis (Kinnear \& Gray 1994).

Factor analysis of depth samples (Table 4) demonstrated that elemental correlations were determined by 3 to 4 factors (each with an eigenvalue $>1$ ). In each case the main factor (Factor 1 ) accounted for 30 to $40 \%$ of the sample variance and the elemental group invariably included $\mathrm{K}, \mathrm{Mg}$ and $\mathrm{P}$. S was also part of Group 1 in 2 of the samples, but no other elements occurred in this group with a positive loading. Factor 2 determined
18 to $24 \%$ of the sample variance and typically included $\mathrm{Cl}$, with $\mathrm{Ca}$ or Fe (or both). Si characteristically either occurred as a separate group (2 and $8 \mathrm{~m}$ samples) or occurred with other elements, but with a negative loading factor.

\section{DISCUSSION}

In this investigation, XRMA has been used to provide information on depth-specific micro-populations of Ceratium from analysis of individual cells

With XRMA, it is important to ensure that X-rays are derived only from the specimen and not from the supporting filter membrane (over-penetration) or from contaminant sources (extraneous peaks). Although the exact depth of penetration of the electron probe into Ceratium cells is not known, previous studies suggest that a $15 \mathrm{kV}$ probe will generate $X$-rays up to a maximum depth of about $10 \mu \mathrm{m}$ (Clay et al. 1991).

At this depth, $X$-rays will be collected from a probe volume extending from the cell wall to the inner regions of the Ceratium cell, with no over-penetration into the filter membrane. The absence of extraneous peaks is indicated by the routine absence of any significant characteristic peaks from control (filter membrane) spectra. During material preparation, all excess lake water is removed during filtration and cells are not exposed to any potentially contaminant solutions during processing. Immediate freezing of the phytoplankton cells on the boat is also important to ensure that no changes occur in the elemental composition of algal 


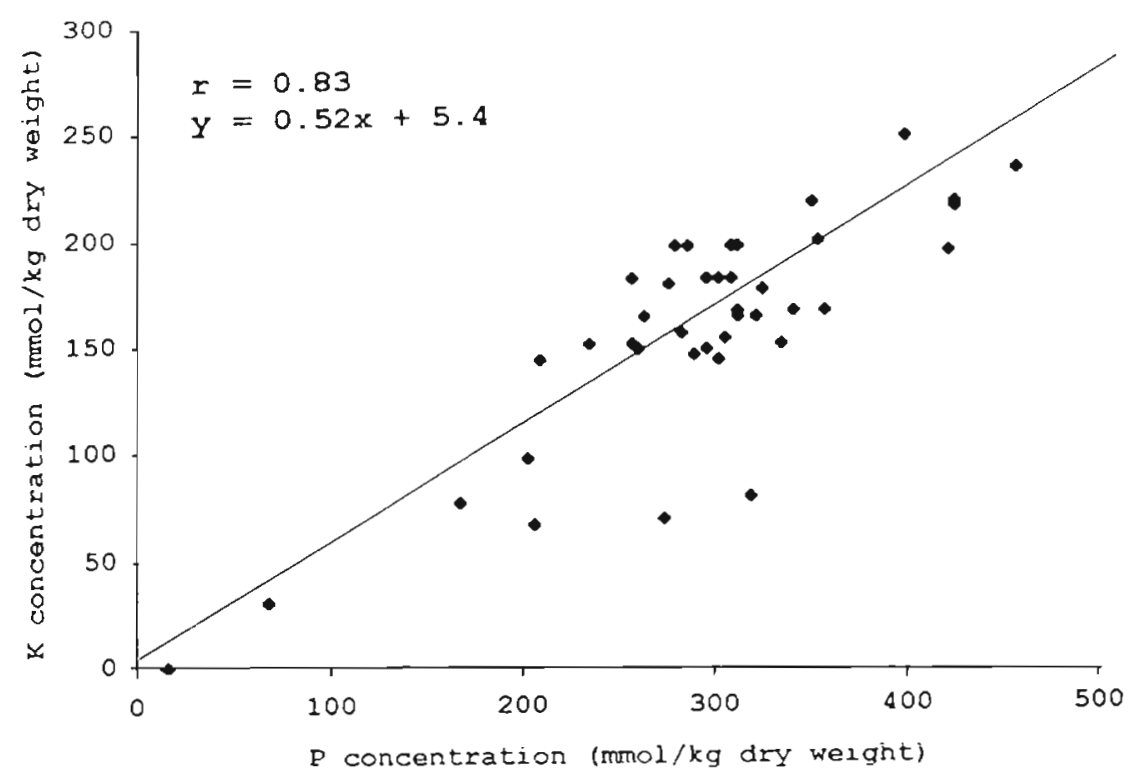

Fig. 5. Correlation between concentrations of $\mathrm{K}$ and $\mathrm{P}$ in cells of Ceratium hirundinella. Data from $5 \mathrm{~m}$ depth sample. $\mathrm{r}=$ correlation coefficient trations of $\mathrm{Mg}, \mathrm{P}, \mathrm{Cl}$ and $\mathrm{K}$. This disparity between internal and external changes would suggest that lower cell concentrations at this depth relate to aspects of cell physiology rather than external elemental availability. Dinoflagellates are known to prefer well-oxygenated conditions (Harris et al. 1979, Pollingher 1988) and the depleted oxygen levels in the metalimnion may induce physiological stress in these cells.

The high concentrations of $\mathrm{Si}$ in all depth samples are particularly interesting, since they show that this element is a major constituent of Ceratium cells in these phytoplankton sampies. Suostantial levels of $\mathrm{Si}$ in Ceratium cells have also been detected in previous studies at this site (Sigee et al. 1998). The cells after isolation from the lake water. The generally high values for the $\mathrm{K} / \mathrm{Na}$ ratio (mean depth sample values of 4.6 to 7.0) are consistent with the cryofixation of the majority of cells in a healthy and unaltered state, comparable to that seen in other rapid-frozen material (Warley 1993, Zierold 1993).

On the date of sampling, the lake population of Ceratium was in the middle of a 2 mo bloom period and occurred throughout the epilimnion and into the metalimnion, within the mixed phytoplankton. Potential differences between cells at different depths were investigated in relation to 3 main aspects - elemental concentrations, constancy of elemental and ionic ratios and patterns of elemental correlation.

\section{Elemental concentrations}

With the exception of Si (see below) mean elemental concentrations generally showed little variation throughout the epilimnion ( 0 to $5 \mathrm{~m}$ depths). This is in line with the lake water concentrations, which also showed uniformity in concentrations of major anions and cations. Significant differences were, however, noted at the $8 \mathrm{~m}$ depth. Transition from the epilimnion to the metalimnion showed a reduced Ceratium cell count and a sharp fall in the overall phytoplankton biomass. This was reflected in higher lake water concentrations of major anions ( $N, P, S$ ) and cations ( $M g, K$, $\mathrm{Ca}$. In contrast to the higher external levels of these elements, mean cell concentrations were typically significantly lower at the $8 \mathrm{~m}$ depth-including concen-
Table 4. Factor analysis of depth samples. For each depth, elements are grouped in relation to principal factors that determine their correlation. Elements detected in $<50 \%$ analyses are excluded from the analysis. The Kaiser-Meyer-Olkin (KMO) measure of sampling adequacy was typically $>0.5$, and the Bartlett test $(B T)$ of sphericity was significant $(<0.05)$ in all cases. Loading factors from the rotated factor matrix (varimax) are given for each element, with the exclusion of all elements having a loading factor $<0.5$. Minimum percentages of variance ( ) were $30 \%$ (Factor 1), 18\% (Factor 2) and $13 \%$ (Factor 3)

\begin{tabular}{|c|c|c|c|c|}
\hline Depth (m) & Factor 1 & Factor 2 & Factor 3 & Factor 4 \\
\hline 0 & $(30.0 \%)^{\circ}$ & $(18.0 \%)^{\circ}$ & $(15.5 \%)^{\circ}$ & \\
\hline $\mathrm{KMO}=0.37$ & $\mathrm{~K}(0.71)$ & $\mathrm{Cl}(0.63)$ & $\mathrm{Ca}(0.63)$ & \\
\hline $\mathrm{BT}=0.00003$ & $\begin{array}{l}\mathrm{Mg}(0.76) \\
\mathrm{P}(0.89)\end{array}$ & Si $(-0.75)$ & $S(0.82)$ & \\
\hline 1 & $(35.0 \%)^{\circ}$ & $(19.6 \%)^{\circ}$ & $(15.3 \%)^{\circ}$ & $(13.0 \%)$ \\
\hline $\mathrm{KMO}=0.52$ & $K(0.94)$ & $\mathrm{Ca}(0.9)$ & $\mathrm{Cl}(0.9)$ & $\mathrm{Fe}(0.71)$ \\
\hline $\mathrm{BT}=0$ & $\begin{array}{l}\mathrm{Mg}(0.67) \\
\mathrm{P}(0.93)\end{array}$ & $\mathrm{Fe}(0.52)$ & $\mathrm{Fe}(0.52)$ & Si $(0.76)$ \\
\hline 2 & $(38.9 \%)^{\circ}$ & $(18.0 \%)^{\circ}$ & $(13.1 \%)^{\circ}$ & \\
\hline $\mathrm{KMO}=0.66$ & $\mathrm{~K}(0.76)$ & $\mathrm{Ca}(0.65)$ & Si $(0.95)$ & \\
\hline $\mathrm{BT}=0$ & $\begin{array}{l}\mathrm{Mg}(0.76) \\
\mathrm{P}(0.91) \\
\mathrm{S}(0.79)\end{array}$ & $\begin{array}{l}\mathrm{Cl}(0.78) \\
\mathrm{Fe}(0.66)\end{array}$ & & \\
\hline 5 & $(35.2)^{\circ}$ & $(23.4)^{\bullet}$ & $(13.5)^{*}$ & \\
\hline $\mathrm{KMO}=0.52$ & $\mathrm{~K}(0.98)$ & $\mathrm{Cl}(0.77)$ & Ca $(0.93)$ & \\
\hline $\mathrm{BT}=0$ & $\begin{array}{l}\mathrm{Mg}(0.62) \\
\mathrm{P}(0.88) \\
\mathrm{Si}(-0.62)\end{array}$ & $\begin{array}{l}\text { Fe }(0.64) \\
S(0.76)\end{array}$ & & \\
\hline 8 & $(40.9 \%)$ & $(21.4 \%)^{\circ}$ & $(14.5 \%)^{\circ}$ & \\
\hline $\mathrm{KMO}=0.63$ & $K(0.85)$ & $\mathrm{Ca}(0.80)$ & Si $(0.96)$ & \\
\hline $\mathrm{BT}=0$ & $\begin{array}{l}\mathrm{Mg}(0.70) \\
\mathrm{P}(0.90) \\
\mathrm{S}(0.81)\end{array}$ & $\mathrm{Cl}(0.89)$ & & \\
\hline
\end{tabular}


higher cell concentrations of $\mathrm{Si}$ at 5 and $8 \mathrm{~m}$ parallel significantly higher lake water concentrations at these depths, suggesting a possible relationship (e.g. direct adsorption onto the cell surface from externally elevated concentrations). Elemental correlation studies (see later) are consistent with Si being a cell wall constituent, and an alternative possibility is that Ceratium cells with a high Si deposition have a higher overall density and are less able to maintain their position within the water column by cell motility.

\section{Elemental variation within micro-populations}

Concentrations of elements within cells showed a wide variation within the 40 -cell population samples. This variation was generally similar to that seen previously (Sigee et al. 1998) for Ceratium in integrated depth samples (e.g. phosphorus 45 to 281, potassium

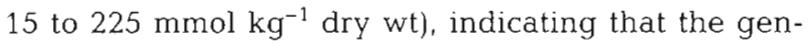
eral variation in elemental concentrations could not simply be attributed to collection of cells from different depths. Similar variation within algal species has also been noted from other XRMA studies, including both field populations (El-Bestawy et al. 1996, Sigee \& Holland 1997) and laboratory cultures (Fagerbakke et al. 1991). This variation seen in XRMA data is considerabiy greater than the \pm 3 to $6 \%$ iimits of accuracy inherent in the technique (Ingram \& Ingram 1980, Lyman et al. 1990), suggesting that variation between analyses reflects genuine variation in the samples. Using an alternative approach (chemiluminescence) Villareal \& Lipschultz (1995) noted wide variations in the nitrate concentration of marine diatoms.

The general approximation to a normal distribution suggests that differences between most cells within the micro-populations were part of a broad continuum. A small proportion of cells, however, with low concentrations of $\mathrm{K}$ and other elements, did not fit into this continuum and appeared to form a discrete sub-population. Major loss of $\mathrm{K}$ and other soluble constituents has been used as a criterion of cell death in other algae (Peterson et al. 1995, Lee \& Rhee 1997) and the low-K sub-population detected in these environmental samples may represent a fraction of cells that are undergoing senescence. The lower $\mathrm{K} / \mathrm{Na}$ ratio in thses cells (1.2 compared to overall values of 4.6 to 7.9 ) may also specifically indicate a reduced viability (Zierold 1993). If this interpretation is correct, then cell death is detected in about $5 \%$ of the total Ceratium population, and occurs throughout most of the sampled water column. These data, from an actively growing field population of Ceratium, may be compared to values of 1.5 and $3 \%$ obtained respectively for exponential and stationary phase batch cultures of the dinoflagellate Peridinium, increasing to values of up to $62 \%$ during final population decline (Pollingher 1988).

\section{Elemental and ionic ratios}

Comparison of elemental ratios in the different depth samples demonstrated a remarkable constancy throughout the sampled water column, with 10 ratios having an SE of less than $5 \%$ of the mean. Previous studies on Ceratium populations over an extended time period (Sigee et al. 1998) also demonstrated fixed ratios of certain elements - particularly $\mathrm{Mg} / \mathrm{K}, \mathrm{P} / \mathrm{K}$ and $\mathrm{Mg} / \mathrm{P}$. The values of these ratios were very similar to those seen in the present study, but the general constancy of elemental ratios was considerably less. In both studies, elemental ratios involving $\mathrm{Si}, \mathrm{Ca}$ and $\mathrm{Fe}$ showed no constancy between samples.

Although XRMA does not provide information on the ionic status of particular elements, or whether they are fixed or bound, some inferences can be made on the balance of detectable inorganic ions in cells. Constancy in the ratios of monovalent/divalent cations and diffusible anions/cations between samples indicates a high degree of consistency in the ionic balance of cells through the water column. These ratios are maintained even where there are significant differences in cell and environmental concentrations with depth. The ratio of monovalent/divalent cations appears to be particularly relevant, since a significant correlation was found between these 2 groups within all population samples. Constancy in the monovalent/divalent cation ratio was also noted previously for the Ceratium time-course data (Sigee et al. 1998), where the ratio was similar to the present study.

\section{Elemental correlation pattern}

Correlations between elemental concentrations within individual XRMA analyses can provide useful information on statistical associations within phytoplankton cells (El-Bestawy et al. 1996, Sigee \& Holland 1997. Sigee et al. 1998).

Major correlations between particular pairs of elements were also noted in the present study -2 of which (Mg-P, K-P) were statistically significant in all depth samples. The overall pattern of statistical associations suggests an interconnected group of 4 elements-Mg, S, K and P. Previous studies of Ceratium (Sigee et al. 1998) indicated a closely similar correlation pattern, with an $\mathrm{Mg}, \mathrm{S}, \mathrm{K}$ and $\mathrm{P}$ core, but differing in the association of $\mathrm{Cl}$. 
The statistical associations indicated by the correlation analysis reflect specific associations within cells and do not simply relate to abundance of the particular elements. This is shown by the fact that some combinations of major elements, such as $\mathrm{K}-\mathrm{Cl}$ and $\mathrm{P}-\mathrm{Cl}$, do not show any positive correlations. Furthermore, $\mathrm{Si}-$ which is present at high levels in all samples - does not show any significant positive correlations with any other elements. Positive correlations may reflect occurrence of elements in similar cell compartments, or direct chemical association. $\mathrm{P}$ is known, for example, to be chemically associated with a range of metals in polyphosphate bodies (Peverley et al. 1978, Baxter \& Jensen 1980, Jensen et al. 1982, Siderius et al. 1996).

The pattern of elemental associations derived from correlation coefficients is corroborated by factor (principal component) analysis. For each depth sample, the central core of 4 elements is identified as the major group (determined by Factor 1) - which includes Mg, K and $\mathrm{P}$, plus (in 2 cases) $\mathrm{S}$. Cl, Fe and $\mathrm{Ca}$ are not part of the Factor 1 group in any samples. The XRMA data provide no information on the nature of the determinant factors. Factor 1, for example, may represent insoluble components of the cytoplasm, while Factor 2 might be mainly soluble components. Dinoflagellates are known to have high levels of nuclear DNA associated with cations (Sigee 1986), and the clear grouping of $P$ with cations in the Factor 1 group may relate to this.

\section{Conclusions}

In the present study, comparison of Ceratium populations at different depths suggests close similarities within the top $8 \mathrm{~m}$ of the water column. Although significant differences in mean elemental concentration do occur with depth, particularly in relation to Si and for cells below the epilimnion, the main inference is one of underlying homogeneity - with similarities in elemental and ionic ratios and elemental correlations throughout the water column. Even sub-populations of low-K (possibly senescing) cells are dispersed throughout most of the sampled depth. The XRMA data support the idea of a phenotypically continuous population of Ceratium within the sampled water column, with cells throughout sharing some fundamental aspects of elemental composition - but with some variation in relation to local depth conditions. This underlying homogeneity would result from a highly mobile and intermixed population of cells, and is in agreement with the known ability of Ceratium to carry out major vertical migrations and to rapidly regulate its vertical position within the water column (Heaney \& Talling 1980, Reynolds 1990). Comparative studies are currently underway to investigate elemental depth varia- tion in other algae, for which factors other than cell motility (buoyancy, water turbulence) determine the position within the water column.

Acknowledgements. We would like to record our thanks to English Nature for permission to carry out sampling at Rostherne Mere and for provision of boating facilites. We are particularly grateful to the Warden, Mr Martin Davey, for all his help and encouragement.

\section{LITERATURE CITED}

Baxter M, Jensen T (1980) Uptake of magnesium, strontium, barium and manganese by Plectonema boryanum (Cyanophyceae) with special reference to polyphosphate bodies. Protoplasma 104:81-89

Behrendt H (1990) The chemical composition of phytoplankton and zooplankton in a eutrophic lake. Arch Hydrobiol 118:129-145

Booth KN, Sigee DC, Bellinger E (1987) Studies on the occurrence and elemental composition of bacteria in freshwater phytoplankton. Scanning Microsc 1:2033-2042

Brook AJ. Grime GW, Watt F (1988) A study of barium accumulation in desmids using the Oxford scanning proton microprobe (SPM). Nuc Instrum Methods Phys Res B30: $372-377$

Carvalho L, Beklioglu M, Moss D (1995) Changes in a deep lake following sewage diversion - a challenge to the orthodoxy of external phosphorus control as a restoration strategy. Freshw Biol 34:399-410

Clay S, Sigee DC, Bellinger E (1991) X-ray microanalytical studies of freshwater biota: changes in the elemental composition of Anabaena spiroides during blooms of 1988 and 1989. Scanning Microse 5:207-217

El-Bestawy E, Bellinger E, Sigee DC (1996) Elemental composition of phytoplankton in a subtropical lake: X-ray microanalytical studies on the dominant algae Spirulina and Cyclotella. Eur J Phycol 31:157-166

Fagerbakke KM, Heldal M, Norland S (1991) Variation in elemental content among and within trichomes in Nostoc calcicola 79WA01 measured by X-ray microanalysis. FEMS Microbiol Lett 81:227-232

Hall SR, Sigee DC, Beesley JE (1992) Scanning X-ray microanalysis of microcarrier cultured endothelial cells: elemental changes during the transition to confluency and the effect of ionophore A23187. Scan Microsc 6:753-763

Harris GP, Heaney SY, Talling JF (1979) Physiological and environmental constraints in the ecology of the planktonic dinoflagellate Ceratium hirundinella. Freshw Biol 9: 4.13-428

Heaney SI, Talling JF (1980) Dynamic aspects of dinoflagellate distribution patterns in a small, productive lake. J Ecol $68: 75-94$

Höll K (1928) Ökologie der Perideneen. Studien über den Einfluss chemischer und physikalischer Faktoren auf die Verbreitung der Dinoflagellaten im Süsswasser. Pflanzenforsch Jena No. 11

Ingram FD, Ingram MJ (1980) Quantitative X-ray microanalysis of bulk specimens. In: Hayat MA (ed) X-ray microanalysis in biology. Macmillan, London, p 367-399

Jensen TE, Baxter M, Rachlin JW, Jani V (1982) Uptake of heavy metals by Plectonema boryanum (Cyanophyceae) into cellular components, especially polyphosphate bodies: an X-ray dispersive study. Environ Pollut Ser A 27 : $119-127$ 
Jespersen A, Christoffersen K (1987) Measurements of chlorophyll-a from phytoplankton using ethanol as extraction solvent. Arch Hydrobiol 109:445-454

Kinnear PR, Gray CD (1994) SPSS for windows. Lawrence Erlbaum Associates, Hillsdale

Krivtsov V, Bellinger E, Sigee DC, Corliss J (1998) Application of SEM XRMA data to lake ecosystem modelling. Ecol Model 113:95-123

Lee DY, Rhee GY (1997) Kinetics of cell death in the cyanobacterium Anabaena flos-aquae and the production of dissolved organic carbon. J Phycol 33:991-998

Lyman CE, Goldstein JI, Romig AD, Echlin P, Joy DC, Newbury DE, Williams DB, Armstrong JT, Fiori CE, Lifshin E, Peters K (1990) Scanning electron microscopy, X-ray microanalysis, and analytical electron microscopy. Plenum Press, New York

Moss B, Beklioglu M, Carvalho L, Kilinc S, McGowan S, Stephen D (1997) Vertically-challenged limnology: contrasts between deep and shallow lakes. Hydrobiologia $342: 257-267$

Peterson HG, Hrudey SE, Cantin IL, Perley TR, Kenefick SL (1995) Physiological toxicity, cell membrane damage and the release of dissolved organic carbon and geosmin by Aphanizomenon flos-aquae after exposure to water treatment chemicals. Wat Res 29:1515-1523

Peverley JH, Adamec J, Parthasarathy MV (1978) Association of potassium and some other monovalent cations with the occurrence of polyphosphate bodies in Chlorella. Plant Physiol 62:120-126

Pollingher U (1988) Freshwater armoured dinoflagellates: growth, reproduction strategies and population dynamics. In: Sandgren CD (ed) Growth and reproductive strategies of freshwater phytoplankton. Cambridge University Press, Cambridge, p 134-174

Reynolds CS (1990) The ecology of freshwater phytoplankton. Cambridge University Press, Cambridge

Editorial responsibility: Frede Thingstad,

Bergen, Norway
Reynolds CS, Bellinger EG (1992) Patterns of abundance and dominance of the phytoplankton of Rostherne Mere, England: evidence from an 18-year data set. Aquat Sci 54: $10-38$

Siderius M, Musgrave A, Van Den Ende H, Kuerten H, Cambier P, Van Der Meer P (1996) Chlamydomonas eugametos (Chlorophyta) stores phosphate in polyphosphate bodies together with calcium. J Phycol 32:402-409

Sigee DC (1986) The dinoflagellate chromosome. In: Callow J (ed) Advances in botanical research, Vol 12. Academic Press, London, p 205-264

Sigee DC, Holland R (1997) Elemental composition, correlations and ratios within a population of Staurastrum planktonicum: an X-ray microanalytical study. J Phycol 33: $182-190$

Sigee DC, Morgan AJ, Sumner AT, Warley A (1993) X-ray microanalysis in biology: experimental techniques and applications. Cambridge University Press, Cambridge

Sigee DC, Krivtsov V, Bellinger EG (1998) Elemental concentrations, correlations and ratios in micropopulations of Ceratium hirundinella (Pyrrhophyta): an X-ray microanalytical study. Eur J Phycol 33:155-164

Villareal TA, Lipschultz F (1995) Internal nitrate concentrations in single cells of large phytoplankton from the Sargasso Sea. J Phycol 31:689-696

Warley A (1993) Quantitative X-ray microanalysis of thin sections in biology: appraisal and interpretation of results. In: Sigee DC, Morgan AJ, Sumner AT, Warley A (eds) Xray microanalysis in biology: experimental techniques and applications. Cambridge University Press, Cambridge p $47-57$

Zierold K (1993) Rapid freezing techniques for biological electron probe microanalysis. In: Sigee DC, Morgan AJ, Sumner $A T$, Warley $A$ (eds) $X$-ray microanalysis in biology: experimental techniques and applications. Cambridge University Press, Cambridge, p 101-116

Submitted: October 2, 1998; Accepted: March 1, 1999 Proofs received from author(s): September 7, 1999 